vide a link to terrestrial limnic records as derived from varved evaporitic sediments of the Dead Sea to the north (e.g., Heim et al., 1997) but also to other marine records as derived from varved oxygenminimum-zone sediments of the Arabian Sea to the south (von Rad et al., 1999) which documents variations in the intensity of the Asian monsoon. The coral-based paleoclimatic records will also support terrestrial reconstructions and model simulations of Holocene climate variability in the Saharan and Arabian region (e.g., Hoelzmann et al., 1998; Claussen et al., 1999). Furthermore, the studies will contribute to other paleoenvironmental research along the PAGESPole-Equator-Pole transect which passes through Europe and Africa (PEP III) (Gasse et al., 1997).

\section{References}

Beck, J.W. et al. 1992. Science, 257, 644-647.

Claussen, M. et al. 1999. Geophys. Res. Lett., 26, 2037-2040.

CLIMAP 1981. GSA Map and Chart Ser. MC-36. Boulder, CO. Geol. Soc. of Am.

DeVilliers, S. et al. 1994. Geochim. Cosmochim. Acta, 58, 197-208.

DeVilliers, S. et al. 1995. Science, 269, 1247-1249.

Dunbar, R.B. \& Cole, J.E. 1999. Annual Records of Tropical Systems (ARTS). PAGES Workshop Report 99-1, 72 pp.

Eisenhaver, A., et al. Chemical Geology, in press.

Felis, T.et al. 1998. J. Geophys. Res., 103,

30731-30739.

Felis, T. et al. 1999. AGU, 80(46) Fall Meet. Suppl., F575.

Gagan, M. K. et al. 1994. Earth Planet. Sci. Lett., 121, 549-558.

Gasse, F. et al. 1997. PEP III: The Pole-Equator-Pole transect through Europe and Africa. PAGES Workshop Report 97-2, 64 pp.

Heim, C. et al.1997. Naturwissenschaften, 84, 398-401.

Hoelzmann, P. et al. 1998. Global Biogeochem. Cycles, 12, 35-51.

Klein, R. et al.1997. Earth Planet. Sci. Lett.,148, pp. 381-394.

Moustafa, Y. A. et al. 2000. Int. Journ. Earth Sciences, in press.

von Rad, U. et al. 1999. Quat. Res., 51, 39-53.

\section{Jürgen Pätzold}

Fachbereich Geowissenschaften, Universität Bremen, Germany

juergen.paetzold@uni-bremen.de

\section{Christian Dullo}

GEOMAR Forschungszentrum Kiel, Germany

cdullo@geomar.de

\title{
Late-Glacial and Early-Holocene Climate Reconstructions at Kråkenes Lake, a West Norwegian Point on PEP III
}

Terrestrial plants and animals respond directly to climatic change when their tolerance thresholds are crossed. However, organisms are not independent like physical measurements but interact in ecosystems where feedbacks apply according to their physiological and ecological tolerances and their population structure (including their biogeography). Ecosystem stability is ultimately controlled by climate, so organisms still show a climatic signal. The signals can be quantified by relating modern organism assemblages to climate (or any measured environmental variable) as a calibration (transfer) function which can then be used to reconstruct quantitatively the past environmental parameters from fossil assemblages. For Europe climate calibration functions currently exist for pollen, Chironomidae, Cladocera, diatoms, and Coleoptera. Indicator species and analogue (assemblage) approaches (e.g. plant macrofossils) can also be used to make quantitative paleoclimatic reconstructions.

For calculation of the magnitudes and rates of past climatic change, multi-proxy studies from high-resolution sequences with calendar chronologies are needed. One such study is the recently completed Kråkenes Project (Kråkenes Project, 2000; Birks et al., 1996; Birks \& Wright, 2000). To detect regional patterns in past climatic change, a comprehensive array of sites is needed covering critical climatic and vegetational boundaries (ecotones), for example the PEP III transect for which the Kråkenes Project results in western Norway comprise an important reference point for the late-glacial and early Holocene. This note briefly presents some climatic conclusions of the Kråkenes Project and shows how multi-proxy biotic responses utilising the sensitivity of organisms to climate at terrestrial sites can be used to reconstruct late-glacial temperature values and the magnitudes and rates of temperature change. It demonstrates the potential of terrestrial sites and organisms for paleoclimatic reconstruction using modern paleoclimatic approaches on fossil organisms.

Kråkenes Lake is exceptional in western Norway because it was deglaciated during the Allerød period (ca. 14,000 cal
BP) but a cirque glacier developed in its catchment during the Younger Dryas and deposited glacio-lacustrine sediments in the lake (Birks et al., 1996, Gulliksen et al., 1998). The Kråkenes Project mostly utilised a single sediment core covering the late-glacial and early-Holocene periods. The rapid sedimentation rates and the abundance of Salix herbacea leaves in the sediments have allowed a high-resolution ${ }^{14} \mathrm{C}$ date series to be made using terrestrial plant macrofossils and earlyHolocene lake sediment $\left(12,300-8000{ }^{14} \mathrm{C}\right.$ yr BP) that has been calibrated to produce a calendar-year chronology $(14,000-9000$ cal BP) (Gulliksen et al., 1998; Birks et al., 2000). The multi-disciplinary project uses plant macrofossils, pollen, mosses, diatoms, oribatid mites, Chironomidae, Cladocera, Coleoptera, and Trichoptera to reconstruct the ecosystem development and the magnitudes and rates of temperature changes and biotic responses round the Younger Dryas.

The Kråkenes lacustrine sequence was strongly influenced by the development of the Younger Dryas glacier. Temperature rather than precipitation controlled the glacier changes and the biotic responses. Temperature also controlled the initial development at the start of the Holocene, but as it continued to rise over time, ecosystem feedback processes became influential (Birks et al., 2000). Terrestrial and aquatic organisms all reacted rapidly to the large late-glacial climatic changes (at least as fast as the changes registered in ice cores), showing that they are sensitive climatic indicators and are sufficiently mobile to move quickly to new suitable habitats. Species responded individualistically, but in periods of strong, fast climatic changes their responses were telescoped together and altered the whole ecosystem. During more gradual climatic changes (Holocene warming) the individualistic responses were expressed, leading to variable rates of change related to ecosystem changes linked to environmental and catchment feedbacks and climatic thresholds.

Quantitative mean July temperature reconstructions made using different groups and methods are plotted against the calibrated chronology in Fig. 1 (Birks \& 


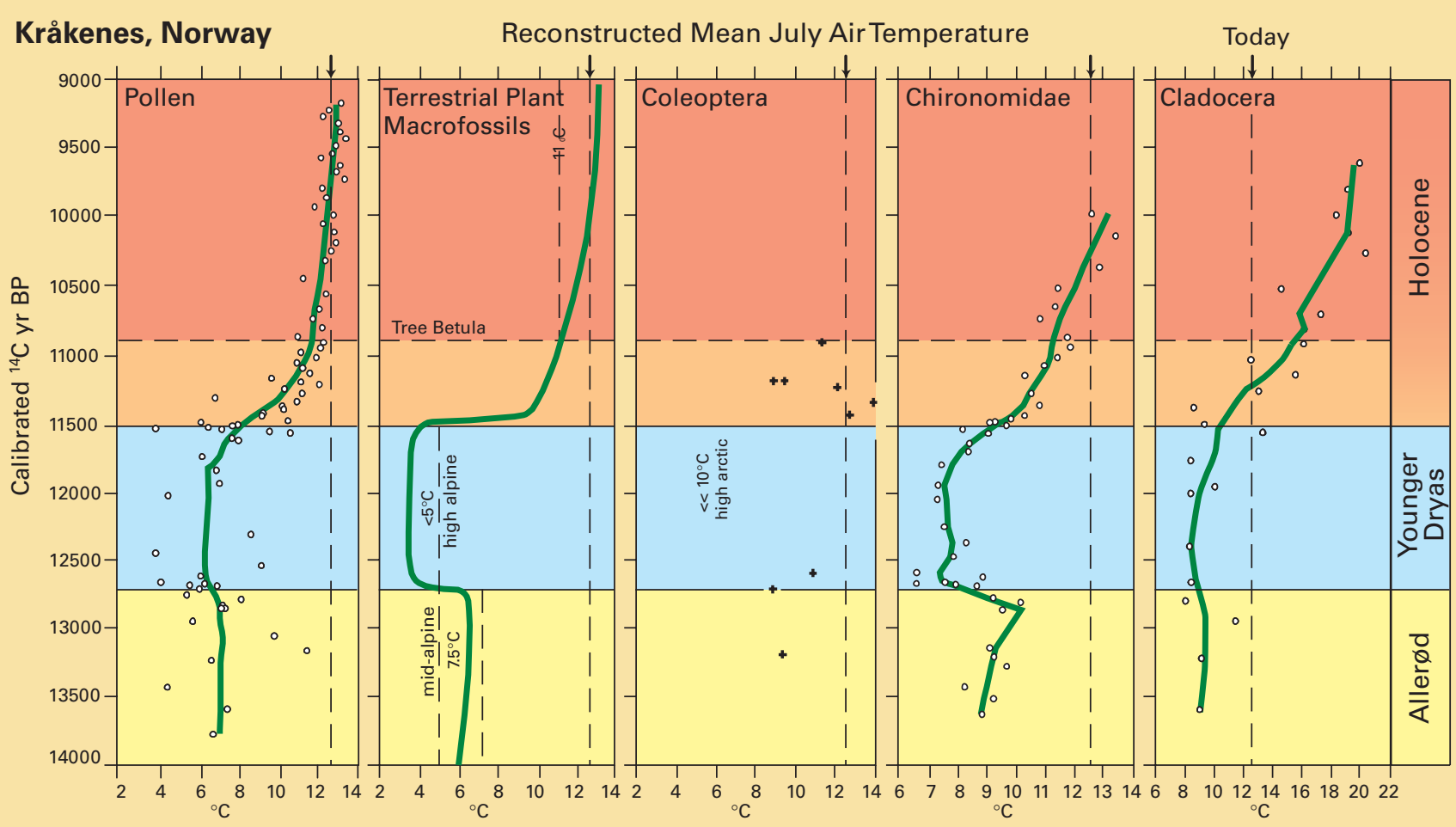

Figure 1: Comparison of mean July air temperature reconstructions at Kråkenes Lake, Norway plotted against calibrated ${ }^{14} \mathrm{C}$ yr. The Allerød interstadial ends at 12,700 ca. BP (Birks et al., 2000), the Younger Dryas at 11,530 $\pm 50 \mathrm{cal}$ BP (Gulliksen et al., 1998), and the first macrofossils of tree birch appear at 10,900 cal BP. Temperatures from pollen (Birks et al., 2000) Chironomidae (Brooks E Birks, in press), and Cladocera (Duigan E Birks, 2000) were reconstructed by modern calibration training sets. The lines are LOESS scatter plot smoothers, spans 0.35 (pollen) and 0.25 (Chironomidae and Cladocera). Coleoptera temperatures (Lemdahl, 2000) were reconstructed by the Mutual Climate Range method. Only a few points are available, so they are not joined. Macrofossil temperatures were inferred by modern vegetation analogues (H.H. Birks, unpublished). The temperatures indicated are at the boundaries of the mid- and high-alpine vegetation zones and the lower limit of Betula pubescens in western Norway today. The present mean July temperature at Kråkenes $\left(12.6^{\circ} \mathrm{C}\right)$ is indicated by a dashed line across the sections. Data are from authors in the Kråkenes Project (2000). Figure from Birks E Ammann (2000).

Ammann, 2000). Calibration data-sets and reconstruction methodology are improving all the time (Birks, 1998) making future climatic reconstructions more sensitive, and other short climatic oscillations have now been revealed in the late-glacial and the early Holocene (Brooks \& Birks, in press). At Kråkenes, the Allerød July temperature was too cool for tree growth $\left(6-9^{\circ} \mathrm{C}\right)$ but not cold enough for local glacier formation. The decrease to the Younger Dryas was about $2^{\circ} \mathrm{C}$ which tipped the balance to glacier formation and resulted in strong responses from all organism groups. The rate of temperature decrease calculated from the chironomid and pollen reconstructions is $0.7^{\circ} \mathrm{C}$ per 25 years for both. Warming initiated in the late Younger Dryas culminated in the melting of the glacier, taken as the lithostratigraphic onset of the Holocene at Kråkenes (Gulliksen et al. 1998). All groups show a steep temperature rise during the first 500 years of the Holocene of ca. $6^{\circ} \mathrm{C}\left(3.5^{\circ} \mathrm{C}\right.$ chironomids), with calculated rates of $0.3^{\circ} \mathrm{C}$ per $25 \mathrm{yr}$ (Cladocera), $0.2^{\circ} \mathrm{C}$ per $25 \mathrm{yr}$ (chironomids), and $0.25^{\circ} \mathrm{C}$ per $25 \mathrm{yr}$ (pollen). The rates then decreased gradually until the modern temperature was reached and exceeded between 10,000 and 9500 cal BP (Birks \& Ammann, 2000). The attainment of $11^{\circ} \mathrm{C}$ (chironomids; Fig. 1) coincides with the local arrival of tree birch, suggesting that its delayed appearance at Kråkenes was due to temperature limitation rather than to migrational lag. The higher temperatures reconstructed from Cladocera probably result from the use of a Swiss calibration set (Duigan \& Birks, 2000) and Coleoptera remains were too few to reconstruct temperatures from each sample (Lemdahl, 2000).

Climatic differentiation in Europe can be detected by comparing the Kråkenes results with those from Gerzensee, Switzerland (Birks \& Ammann, 2000). The magnitudes and rates of temperature changes reconstructed with Swiss calibration sets were similar to those in western Norway, but at a level about $4^{\circ} \mathrm{C}$ warmer. The testing of hypotheses about the causes of late-glacial climatic change needs a geographic spread of paleoclimate data from all available sources (icesheet, ice-core, marine, and terrestrial records). Quantitative estimates of past climates are badly needed from terrestrial ecosystems. These are primary aims of the current Norwegian national project NORPAST and the University of Bergen project NORPEC which are both Norwegian contributions to PAGES PEP III. Paleoclimatic data are also needed for hindcast validation of climate models predicting future climate changes. In this perspective, accurate predictions of the effects of future change on terrestrial ecosystems are of essential relevance to society.

\section{References}

Birks, H.H. \& B. Ammann. Proc. Natl. Acad. Sci. USA 97, 1390-1394, 2000.

Birks H.H., et al. J. Paleolim., 23, 91-144, 2000. Birks, H.H. \& H.E. Wright, J. Paleolim., 23, 1-5, 2000.

Birks H.H. et al. J. Paleolim., 15, 281-286, 1996. Birks, H.J.B., J. Paleolim., 20, 307-332, 1998. Brooks, S.J. \& H.J.B. Birks. Quat. Sci. Rev. (in press). Duigan, C.A. \& H.H. Birks. J. Paleolim., 23, 67-76. Gulliksen, S. et al. The Holocene, 8, 249-259, 1998. Kråkenes Project. Special volume, editors H.H. Birks \& H.E. Wright. J. Paleolim., 23, 1-114, 2000. Lemdahl, G., J. Paleolim., 23, 57-66.

\section{HILARY H. BIRKS}

Botanical Institute, University of Bergen, Norway hilary.birks@bot.vib.no 